Article

\title{
Temporal Scaling of Water Level Fluctuations in Shallow Lakes and Its Impacts on the Lake Eco-Environments
}

\author{
Balati Maihemuti ${ }^{1,2,3}$, Tayierjiang Aishan ${ }^{1,3, *}$, Zibibula Simayi ${ }^{1,2,3, *}$, Yilinuer Alifujiang ${ }^{1,2}$ \\ and Shengtian Yang ${ }^{4}$ \\ 1 College of Resource and Environmental Sciences, Xinjiang University, Urumqi 830046, China; \\ bmaihemuti@xju.edu.cn (B.M.); elnur1103@163.com (Y.A.) \\ 2 Key Laboratory of Xinjiang General Institutions of Higher Learning for Smart City and Environment \\ Modeling, Xinjiang University, Urumqi 830046, China \\ 3 Key Laboratory of Oasis Ecology Xinjiang University, Urumqi 830046, China \\ 4 State Key Laboratory of Remote Sensing Science, School of Geography, Beijing Normal University, \\ Beijing 100875, China; yangshengtian@bnu.edu.cn \\ * Correspondence: tayirjan@xju.edu.cn (T.A.); zibibulla3283@sina.cn (Z.S.)
}

Received: 24 February 2020; Accepted: 15 April 2020; Published: 26 April 2020

\begin{abstract}
Managing lake water levels from an ecological perspective has become an urgent issue in recent years in efforts to protect, conserve, and restore lake eco-environments. In this study, we considered the actual situation of Ebinur Lake basin to develop a lake water balance model using a System Dynamics (SD) method. The objective of this study is based on the lake water balance model to sufficiently understand the variation and relationship between the lake depth-area-volume. We combined field investigations and hydrological data analysis to expose the major factors affecting lake water level fluctuations (WLFs), as well as the impact of WLFs on lake eco-environments. All with the aim of providing a theoretical basis to manage Ebinur Lake ecosystems for conservation and restoration. The main findings of this study include: (I) The model's calculation results agree with the observation value, as the monthly lake surface area was used to validate the model. (II) The factors influencing the dynamic changes in the water level of the lake are ranked in ascending order (from the lowest to the highest) as follows: Precipitation, groundwater recharge, evaporation, river inflow. (III) Fluctuations in water level play a significant role in lake shoreline displacement variation, and when the lake's water level drops below $1 \mathrm{~m}$, the surface area of the water body decreases to approximately $106 \mathrm{~km}^{2}$. (IV) The magnitude and frequency of WLFs drive major differences in the ecology of lake littoral zones, influencing not only the structure and functioning of benthic assemblages but also littoral habitat structure. These results established a quantitative linkage between hydrological variables and ecosystem health for the Ebinur Lake wetlands. These findings could be widely used in managing the Ebinur Lake basin as well as other similar water bodies, and could provide a useful tool for managing lake ecosystems for conservation and restoration.
\end{abstract}

Keywords: water level fluctuation; shallow lakes; Ebinur Lake; lake eco-environments

\section{Introduction}

Water level fluctuations (WLFs) are regarded as critical hydrological factors of lake and shallow lake watersheds. Fluctuations in lake water level have altered habitat availability, complexity, and lake water quality [1] Shallow lakes are very sensitive to WLF in aquatic ecosystems. Depending on the geomorphology of the lake system, relatively minor changes in the water level of a lake can lead to large variations in littoral habitat area $[1,2]$. Thus, deterioration of the eco-environment of the lake 
is related to lake water level variation. WLFs and their ecological and socioeconomic consequences have been investigated in large lakes, e.g., the Aral Sea [3], the Great Salt Lake [4], and the Salton Sea [5] and in small lakes and reservoirs [6,7]. WLF is an important physical factor in managing lake ecosystems for conservation and restoration [8]. Water levels that are too high or too low will cause ecological and environmental damage; when water levels are too high, lake area increases, causing surrounding soil drainage difficulties and probably inducing land degradation, erosion, salinization, alkalization, swapping and gleization of soils, and occupation of arable land for nonagricultural uses. In contrast, when water levels are too low, vegetation degradation occurs, lakes shrink or become dry, plants wilt, land becomes desertified, and dust storms are exacerbated. In recent years, there has been an increasing number of studies addressing the effects of WLFs on lake ecosystems [9-12]. Requirements of WLFs were primarily estimated in several riparian and aquatic plants with simulation experiments and field observations [8,13-16]. These former studies provided a scientific basis for water level evaluations in this shallow lake.

Evaluating the dynamics of water levels in lakes plays a vital role in water resources planning and managing lake ecosystems for conservation and restoration [17]. To date, in the literature, two main approaches are generally used to predict lake WLFs. The first approach is based on an annual lake-volume model, water balance, or water budget, and the second approach is based on a statistical water balance equation that generates seasonal or annual lake volumes based on seasonal climatic variables such as precipitation, evaporation, and surface runoff. The most obvious method to estimate lake water levels is the water balance equation, where water input and output results in lake storage and water level variation [18-20]. In this study, water level variations of Ebinur Lake are simulated using the System Dynamics (SD) model with the water balance equation, which results in mean monthly patterns of lake water levels depending on hydro-climate, inflow-outflow, and lake hydraulic properties [21]. Such information on lake response increases the overall understanding of lake hydrology and can assist in the development of management approaches such as environmental flow concepts for regulating and controlling human water use to provide more stable ecological water levels in lakes, which is to achieve a healthy lake ecosystem target [22].

The SD model, based on nonlinear causal thinking, has been developed to expand the dynamic simulation model; it was originally developed by Forrester in 1961 [23], and it provides a useful tool for understanding the interactions among driving factors and interconnected sub-systems that drive the dynamic behavior of a lake hydrological system [24]. The water levels of lakes are a complex phenomenon, which is mainly controlled by the natural water exchange between a lake and its watershed, and thus lake levels are reflected by hydrological changes in a watershed [17]. In recent years, a number of SD models have been developed for water balance simulation and have been used to evaluate various water-related solutions $[25,26]$ such as hydrologic extremes models [27], water resource planning models [28-30], agriculture water management models [31,32] and water balance models, which have been developed to test water-related and environmental issues in developing countries where data availability is lacking [33,34]. Based on these former studies, the SD model satisfies the requirements for a complex analysis of the Ebinur Lake water level fluctuations and its driving factors.

Ebinur Lake is an endorheic lake in an arid-semiarid basin. While Ebinur Lake is small, it plays a critical role in the conservation and restoration of the Ebinur Lake wetland eco-environments. For the Ebinur Lake basin, it is very important to grasp the trend in water level changes and determine the reasons for the diversification of lake basin water resources, land resources, fishery resources, reed resources, bird resources, biodiversity, and rare species resources. Due to climate change and human activities, extreme low- and high-water level events have occurred more frequently in the past decades, putting great pressure on lake environments [8]. Climate changes and high demand for water use have triggered a series of serious ecological and environmental problems that have caused immeasurable damage. For these reasons, managing Ebinur Lake water levels from an 
ecological perspective is an urgent issue for policy makers, lake managers, and eco-environmental protection agencies.

This project is based on the actual situation of Ebinur Lake basin while developing the lake water balance model and adopting the System Dynamics (SD) method. Exposing the variation and relationship between the lake depth-area-volume and combine it with a hydrological data analysis, finding the major factors that affect lake water level fluctuations and regularities of changes in lake ecosystems, and guaranteeing the sustainable development of this lake eco-environment system are the main target of this study.

\section{Materials and Methods}

\subsection{Site Description}

The Ebinur Lake watershed is located in the lowest elevation of Junggar Basin, Xinjiang Uyghur Autonomous Region of China [35]. It is located in the wind airflow area of the Great Passage of the Alashankou and has the typical ecological and environmental characteristics of inland river basins in arid areas. It is located between latitudes $44^{\circ} 54^{\prime}$ and $\sim 45^{\circ} 08^{\prime}$ and longitudes $82^{\circ} 35^{\prime}$ and $\sim 93^{\circ} 10^{\prime}$, and it is the lowest depression water and salt pool in the western Junggar Basin (Figure 1). Ebinur Lake is the "heart" of the Ebinur Lake basin, and it is a largest salt water lake in Xinjiang, China. Ebinur Lake plays a vital role, and it is a very special and unique ecosystem in the northwestern part of Xinjiang.

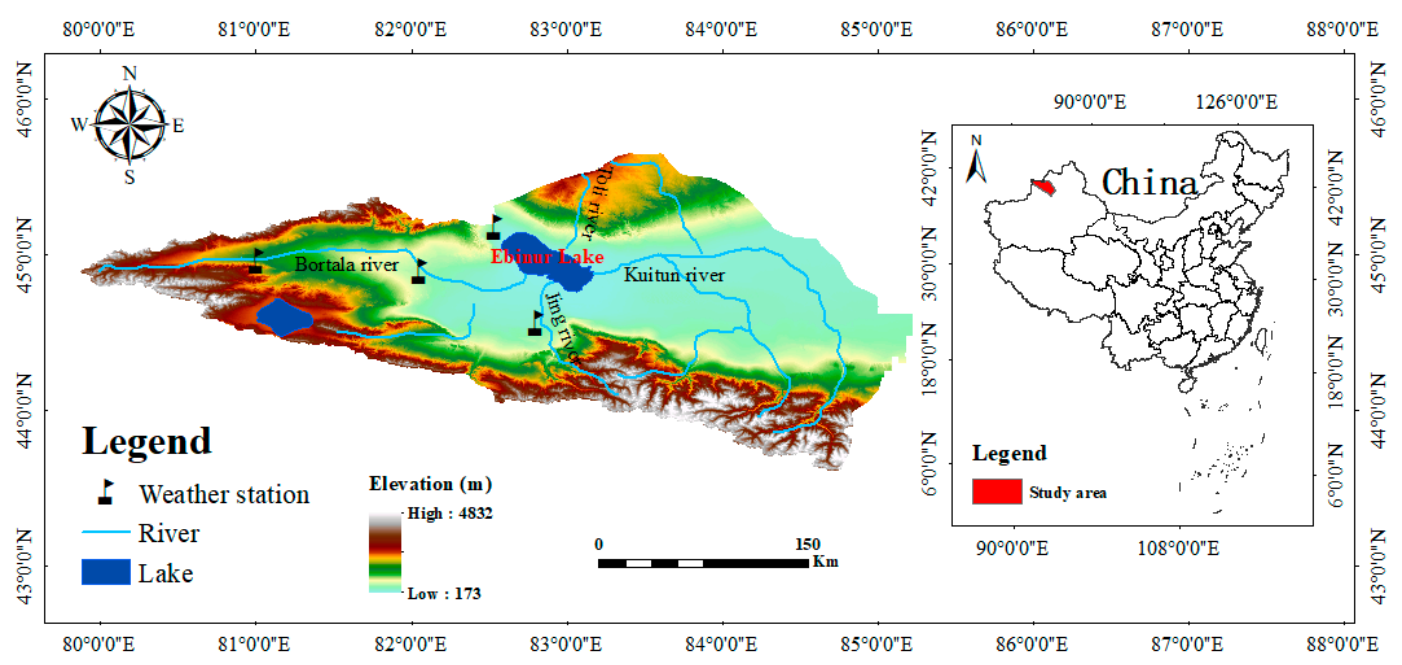

Figure 1. Location of the study region. Ebinur Lake, rivers and streams, and the weather stations.

\subsection{Data Acquisition and Processing}

River and stream runoff data: The surface runoff of this wetland mainly depends on the alpine ice-snow meltwater and rainwater mixed recharge that flows into the stream and rivers. As shown in Figure 1, the Ebinur Lake is a terminal lake and links four rivers, but it is mainly fed by the Bortala River and the Jing River [35], the other two (Toli River and Kuitun River) rivers' flow rates got very small or dried up completely and there are no flow rates into the lake except during the flood season, due to the extension of agriculture water resources security policy in the upstream area. The historical river flow rate data for these rivers were provided by the Water Resources Bureau of Bortala Mongol Autonomous.

Climate data: The Ebinur Lake basin lies within a semiarid to semi-drought subtropical climate zone characterized by a high evaporation rate and low rainfall. The climate of the study area is arid with a mean annual precipitation of 100-200 mm and an annual potential evaporation of 1500 2500 mm [36]. The highest amount of precipitation occurs in summer. In winter, the snow cover is shallow at $10 \sim 25 \mathrm{~cm}$ and persists up to late February or early March. The mean July temperature is $27^{\circ} \mathrm{C}$; the mean January 
temperature is $-17^{\circ} \mathrm{C}$ [37]. Fierce winds usually occur in the region [38]. Weather and hydroclimate databases for this study are obtained from the local Meteorological and Hydrology Stations.

\subsection{Analytical Methods and System Dynamics Model}

The Ebinur Lake is a closed lake, located in the lowest elevation of the Junggar Basin. The amount of water coming from the lake includes precipitation on the lake surface, the amount of surface runoff, and the amount of groundwater inputs to the lake. We conducted a case study the using system dynamics model to developed a lake water balance model for the Ebinur Lake hydrological system, considering high complex hydrogeological conditions, and combining with geomorphological and hydrological analyses (Figure 2).

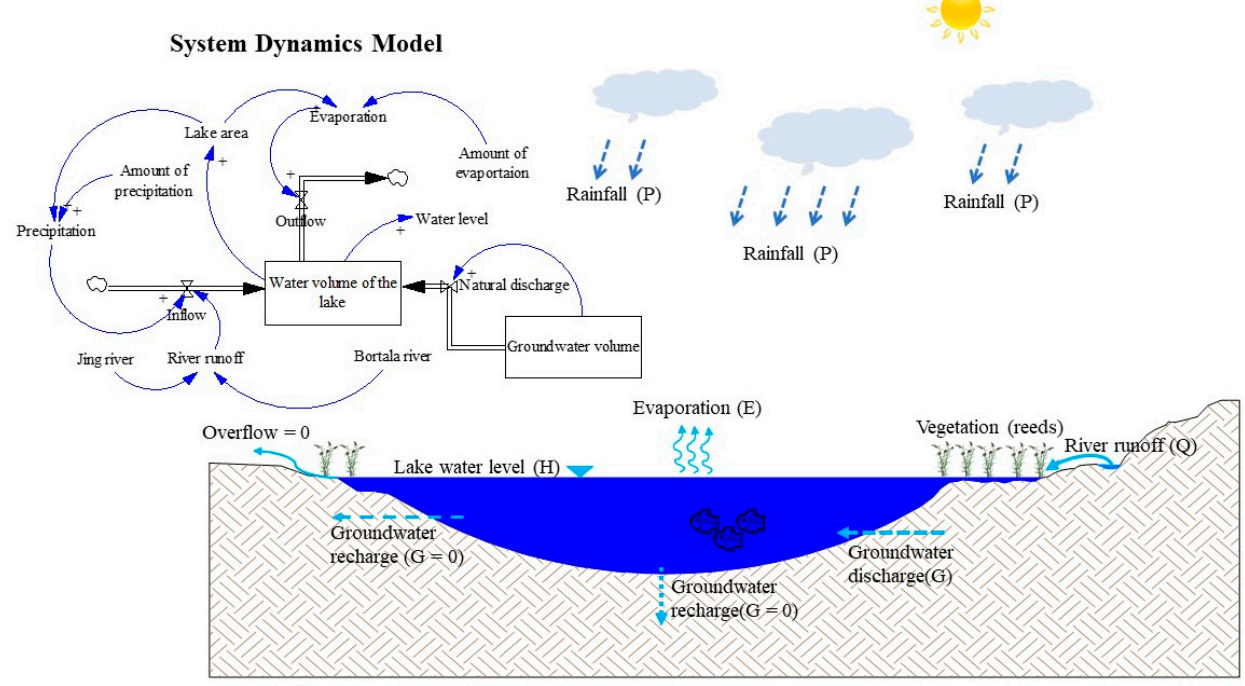

Figure 2. Sketch map of the lake's several inflows and several outflows, and generalized inflow and outflow system of the lake water with System Dynamics (SD) model.

\subsubsection{Model Equations}

To examine the relative magnitude and timing of each of the flows entering and leaving the lake, based on the SD principles and a series of casual loops and mathematical equations, a novel stock-flow diagram was developed for the Ebinur Lake basin, considering the hydrological drivers of the lake water level change and their interactions. In the equations of the SD model, the variables are either stocks or flows. The level of stock $S(t)$ at time point $t$ corresponds to the initial stock level $S\left(t_{0}\right)$ and the integral of its net flow over time [39] as showed follows:

$$
S(t)=S\left(t_{0}\right)+\int_{t_{0}}^{t}[\operatorname{Inflow}(t)-O u t f l o w(t)] d t
$$

where $S\left(t_{0}\right)$ is initial stock levels, $S(t)$ is amount of stock at time $t$, Inflow $(t)$ is inflow at time $t$, Outflow $(t)$ is outflow at time $t$.

\subsubsection{Lake Water Volume}

The Ebinur Lake water volume (storage) is the main stock of the model. Annual (or monthly) changes in the lake's water volume are controlled by the in- and outflow of water. The lake was mainly fed by flowing river water, precipitation, and seepage of groundwater. As the Ebinur Lake is 
an endorheic lake, the outflow is limited to evaporation. The amount of water in the Ebinur Lake at a time $t$ is calculated as follows:

$$
V(t)=V\left(t_{0}\right)+\int_{t_{0}}^{t}[G W(t)+S W(t)+P(t)-E T(t)] d t
$$

where $V\left(t_{0}\right)$ is the water volume of the lake at time $t_{0}, V(t)$ is water volume of the lake at time $t, G W(t)$ is groundwater into the lake at time $t, S W(t)$ is surface water flow at time $t, P(t)$ is precipitation at time $t, E T(t)$ is evaporation from the lake surface at time $t$.

\subsubsection{Groundwater}

Ebinur Lake is located in the center of the basin at the lowest elevation. The special topography and geological structure of Ebinur Lake basin, as well as the groundwater gradient maps, show no evidence for groundwater outflow from the lake and its adjacent aquifers in the region [37]. Potential groundwater recharged from the infiltration of surface runoff, which was made up of alpine glacier melting and mountain precipitation, and then the groundwater flowed slowly towards the lake. The Water Resources Bureau of Bole Mongol Autonomous demonstrated that the amount of this lake replenished by groundwater discharge is approximately $0.9 \times 10^{8} \mathrm{~m}^{3}$ per year [37]. Therefore, only the groundwater inflow into the lake was considered in this simulation.

\subsubsection{Water Level-Area-Volume Relationship}

The lake volume, area, and elevation in different time periods were obtained from the water balance equation [21]. The relationship between water level $(H)$ and lake surface area $(A)$ is expressed [8] as the following equations:

$$
\Delta H=\frac{\Delta V_{t}}{A_{t-1}}
$$

where $\Delta V_{t}$ is the lake water storage change in $t$ time period and is calculated using th water balance model, $A_{t-1}$ is the lake surface area, $\Delta H$ is the lake water level fluctuations.

\section{Results}

\subsection{Analysis of Hydro-Climatic Changes}

Lakes may respond sensitively to climate change in several aspects of hydrology, human activities, and sedimentology [40]. As shown in Figure 3a, the Ebinur Lake surface area rapidly shrunk from 1948 to 1980 because of the extensive expansion of agricultural and industrial development, which induced an increase in water consumption in the area. Since 1980, the lake's surface area has had high amplitude fluctuations, and during 2002-2003, the area of the lake's surface was high, over $900 \mathrm{~km}^{2}$ (as shown in Figure 3a). At this time, the lake submerged the surrounding areas, resulting in catastrophic damage to local economies as well as degradation to the eco-environments. As shown in Figure $4 \mathrm{~b}$, the lake surface area changes were closely related to precipitation, evaporation, and water recharge of the rivers within the lake basins. The amounts of surface water inflow directly affected the lake's surface area changes and its positive correlation as shown Figure 3c. In 2002-2003, the region had elevated temperatures that led to alpine ice and snow melting and increasing river flow rates, as well as surface runoff flowing into dried rivers (Toli River and Kuitun River) and also recharging the lake again. The Bortala meteorological station shows that the daily average air temperatures at the lake ranged from 14 to $30{ }^{\circ} \mathrm{C}$, with peaks from June to July. Due to the alpine ice and snow melting under hot temperatures in July and melting water recharging the Jing River, an increasing flow rate occurred in the Jing River, but the rainfall did not enhance the Bortala River recharge rate (monthly flow rate) because upstream of this river was a reservoir for agricultural water use; therefore, the river flow rate was controlled by human activities (see Figure 3d). Based on our hydrological data analysis results, we know that Ebinur Lake surface regime changes are substantially influenced by anthropogenic 
activities and climate changes. However, human activities (river flow rates were controlled by human activities) had a greater impact than climate changes on the magnitude of river runoff, as well as changes in the lake surface area regimes (Figure 3).
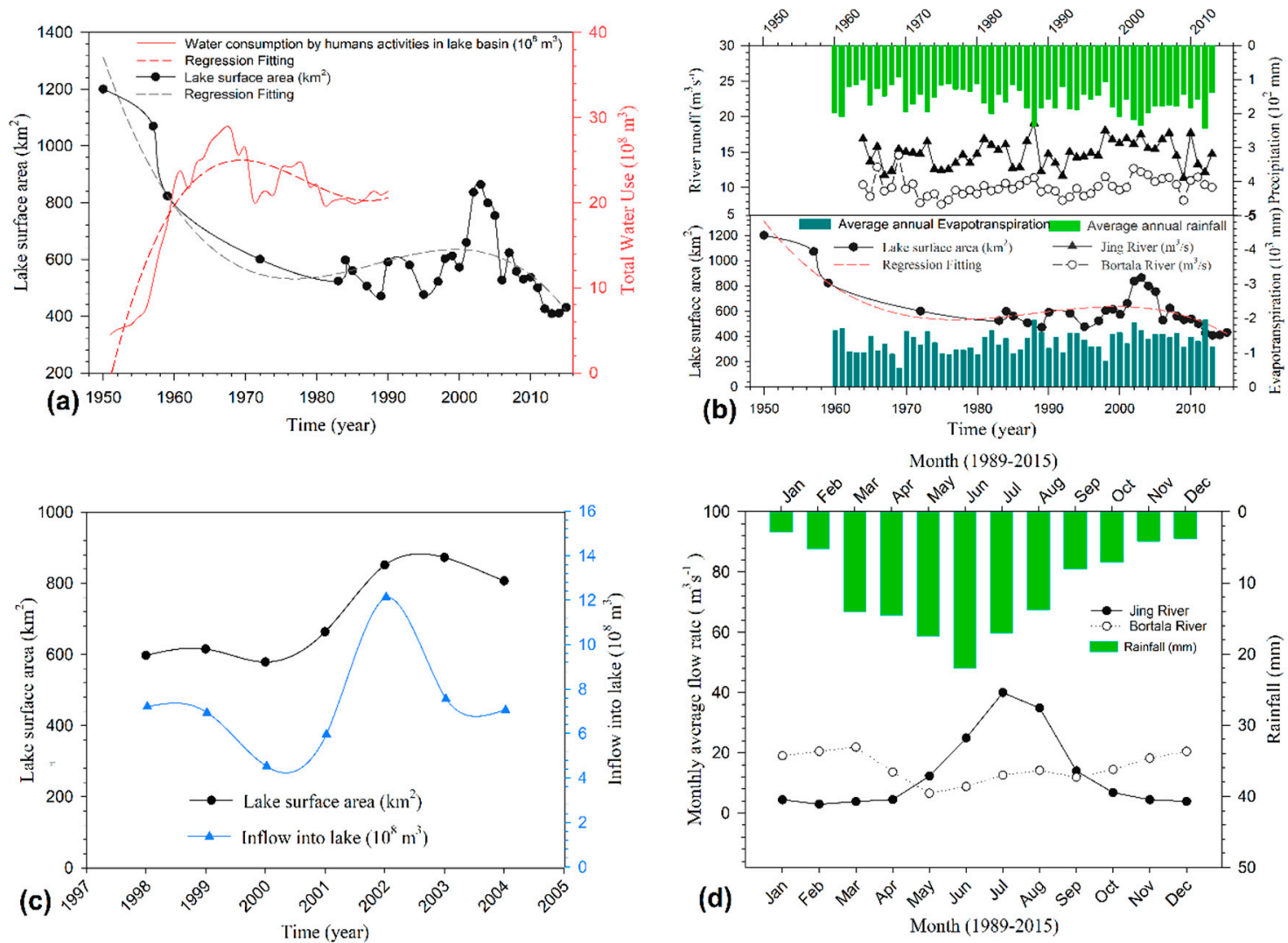

Figure 3. The results of the statistical analysis demonstrate that anthropogenic activities and climate change have impacted the runoff magnitude of the lake water surface regimes. Plot (a) is the water consumption's and lake water surface area changes. Plot (b) is the average monthly rainfall and evapotranspiration, the river recharge rate for the lake, and lake water surface area changes. Plot (c) is the relationship between the surface water inflow into the lake and the lake water surface area changes. Plot (d) is the relationship between the monthly average precipitation and river's monthly average flow rate.
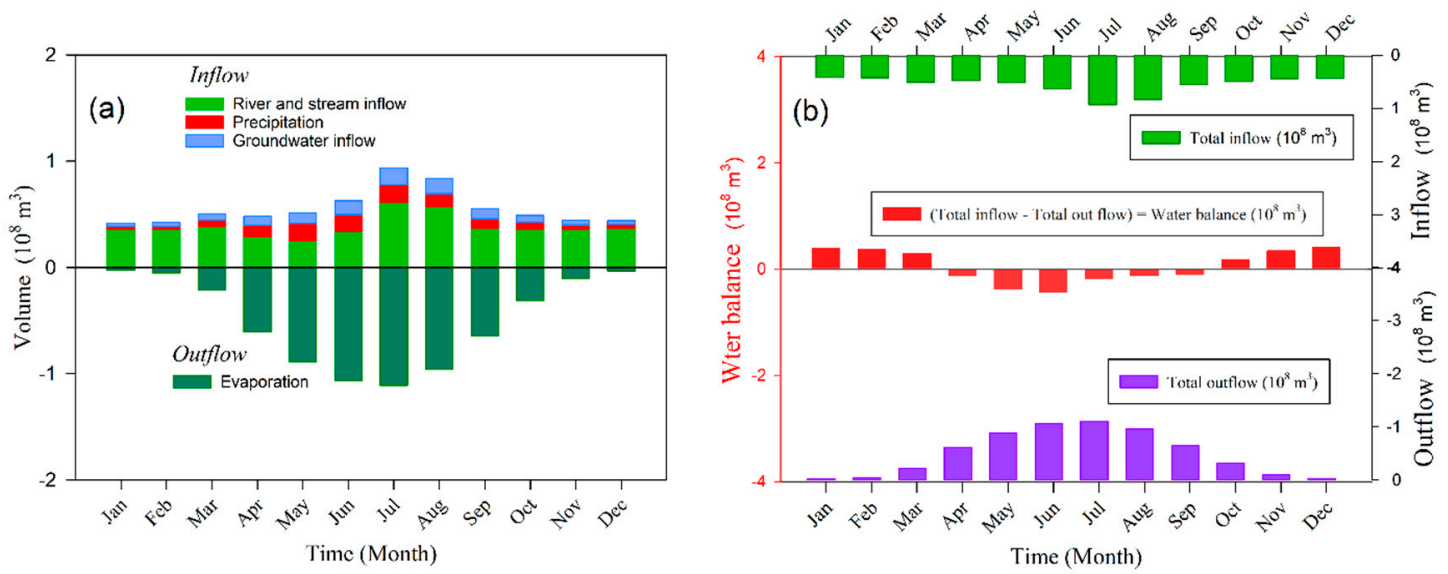

Figure 4. Water balance model results for Ebinur Lake. (a) Monthly water balance for Ebinur Lake. (b) Monthly water storage changes for Ebinur Lake. 
The dry-wet season cycling changes causes changes to WLFs during the year, and from the average monthly rainfall results we know that the summer (November-February) is the dry season, and May-July is the wet season (Figure 3d). The combination of summer drought and intense water use for agriculture reinforces the severity of the problem of the lake's surface shrinking too quickly and inducing degradation of the lake's eco-environment system.

\subsection{Model Calibration and Validation}

The lake water balance modeling approaches used in lake hydrological processes are important for predicting lake water level fluctuations [41]. To test the water balance model based on Equation (1), we used the formula to examine the water volume changes in Ebinur Lake and differences in lake levels. Water volume change is achieved with two consecutive elevation and area values. The water balance can be calculated with the total of all step values [12]. The results of the water balance model (Figure 4a) show that the lake responses to water balance changes are dependent on (1) surface water inflow-outflow, (2) groundwater inflow, (3) rainfall, and (4) evaporation. The exploratory Ebinur Lake water balance analysis presented here describes the hydrologic regime of the lake water shade hydrologic system and provides a meaningful assessment of the inflow and outflow contributions by the various hydrological and hydrometeorological components of this lake system. The results of the water balance in the Ebinur Lake area shown in Figure 4.

The water balance model demonstrates the importance and the influence of the relationships among water level, water volume changes, and lake area variation in a complex hydraulic environment. As shown in Figure $4 \mathrm{~b}$, the monthly water volume changes in Ebinur Lake demonstrate that the amounts of monthly inflow value were greater than the monthly outflow values during 1998, and the water volume experienced an increase of $0.67 \times 10^{8} \mathrm{~m}^{3}$ at that time (shown in Figure $4 \mathrm{~b}$ ). To validate the model, we calculated the lake surface area based on the water balance model and compared that value with monthly observed data (lake water surface area detection using remote sensing) as shown in Figure 5a. Our results (Figure 5) show that the water balance model produces satisfactory simulations that agree with the observed values, which were changes in the value of monthly water surface area $\left(\mathrm{n}=12, \mathrm{R}^{2}=0.83, p<0.001\right)$.
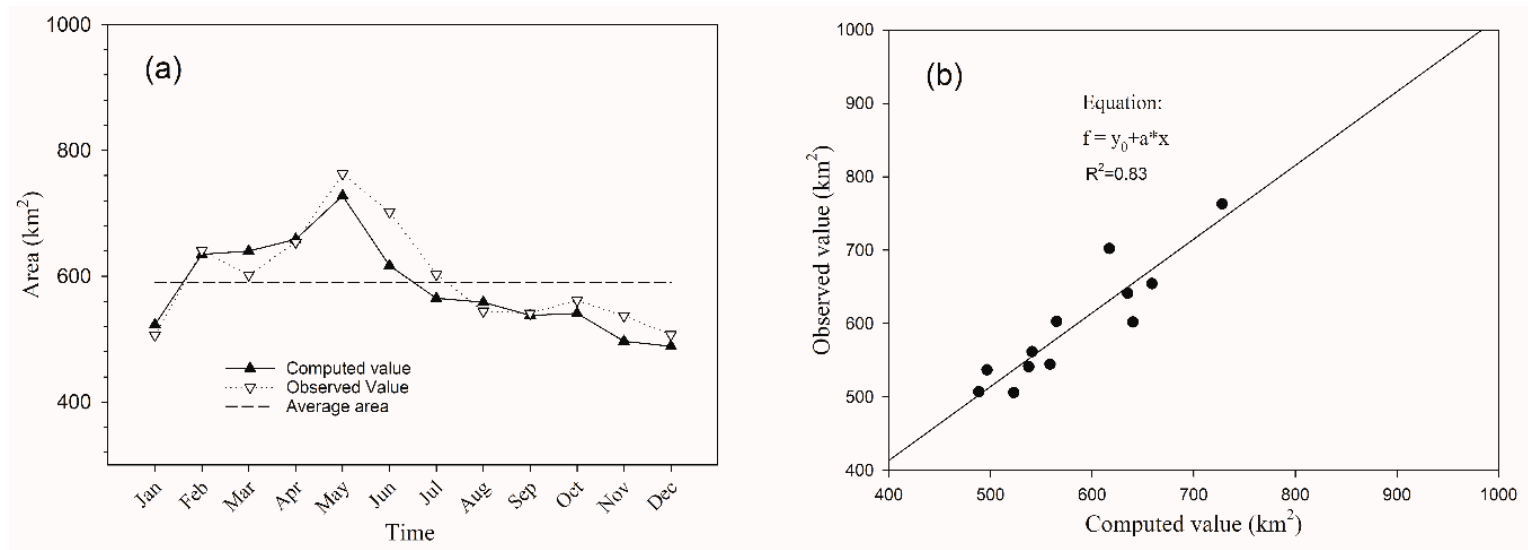

Figure 5. Comparison of model calculated and observed water surface area changes in the lake. Plot (a) is the comparison results of the monthly area value changes. Plot (b) is a comparison of numerical calculation value and observed value.

\section{Discussion}

\subsection{Sensitivity Analysis}

In this study, to predict the degree of sensitivity for lake water level changes, the variable for each state, selected parameters were increased or decreased by about 30\% (Figure 6). A 30\% increase in river 
inflow into the lake would significantly increase the lake water level around $0.2 \mathrm{~m}$, and would alter the lake water surface regimes. A 30\% decrease in evaporation from lake surface water would increase the lake water level close to $0.3 \mathrm{~m}$. A $30 \%$ reduction in precipitation would result in only lowering the water level by $0.05 \mathrm{~m}$. In the same way, the groundwater recharge rates positively correlate with lake water level changes, but do contribute not much more to changes in the lake's water level.

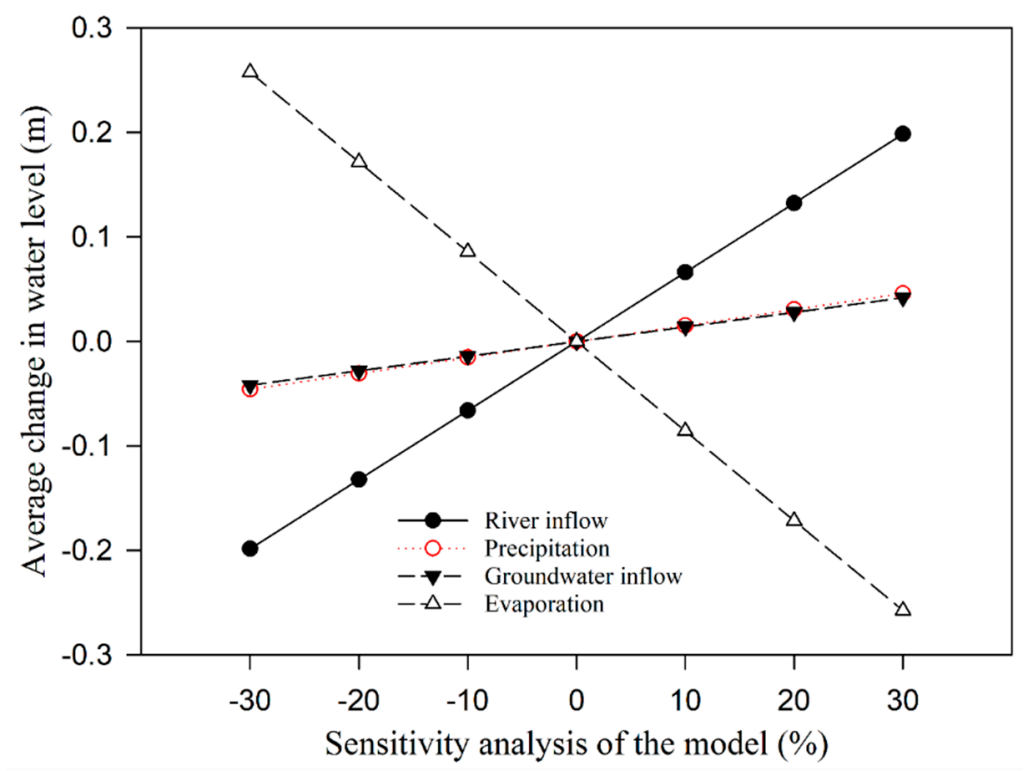

Figure 6. Sensitivity of the predicted water levels to changes in river inflow, precipitation, groundwater inflow, and evaporation rates.

Overall, the model parameters that have the greatest impact on simulation results can also be identified through sensitivity analyses. Lake water levels were most sensitive to variations in river inflow and evaporation rates (see Figure 6). Simulated water levels increased with increasing river inflow and with decreasing evaporation.

\subsection{Ecological Effects and Potential Risks of Lake Water Level Fluctuations}

The site investigation results showed that the biota and species in Ebinur Lake, those living in vegetated areas, respond differentially to changes in hydroperiod dynamics. For example, following the extreme flood at Lake Ebinur in 2002, the reed belts along the shore of the lake lost approximately $3 \times 10^{2} \mathrm{~km}^{2}(37 \%)$ of their beds; that then increased to $44 \%$ in 2003 . However, one-third of this loss was regenerated in the following years 2004 and 2005. These results were obtained for the calculation of the biofilm area provided by the submerged culm parts of the reed stands. The water level's high amplitude fluctuations cause a loss of $47 \%$ of the biofilm's surface area, as was reported by former researchers $[42,43]$. This result reflects the fact that the regeneration of the lakeside stands at lower elevation levels proceeds much more slowly than that of the inner stands at higher elevation levels, which contribute less to the submerged surface areas of the reed stands. However, in dry seasons, the high demand for water consumption in upstream agricultural areas fast decrease the river inflow rate. As a result, these interception actions of river water affect lake water storage, and decrease the lake's water level. Finally, these hydrological changes in the lake's area could cause the reverse succession of the lake ecosystem and lake desert ecosystem, and serious degeneration of and decline in natural vegetation [42]. The reduction in the area of Ebinur Lake caused its salinity to gradually increase and its concentration of lake sediment composition to increase as well [44]. In addition, heavy metals are potentially toxic to ecological systems through the processes of bioaccumulation and biomagnification, and heavy metals are one of the reasons for the sharp decline in the number and types of biodiversity in the Ebinur Lake basin wetland [45]. The results of a recent experiment on Ebinur Lake shores in large 
outdoor experiments demonstrated that amplified WLFs reduce benthicalgal biomass and both the density and taxonomic distinctness of littoral benthic invertebrate assemblages. Furthermore, both the taxonomic and trophic structure of benthic assemblages were altered significantly in the mesocosms with extreme WLFs and these findings fit well with results of former researchers [46]. The results of observational studies in lakes are largely consistent with these findings, indicating that significant WLFs can reduce both the density and diversity of littoral benthic invertebrate assemblages. These findings have important implications for the ecology and biological diversity of standing water ecosystems.

Additionally, Ebinur Lake is located on the wind-gap of the Alashankou, which is a strong wind region. If the water level drawdown causes air-exposed habitats and increases the dry area of the lake bed crust, then it can be eroded by strong wind. The sandstorm and salt powder in the form of suspended particles in the air becomes a natural disaster in this area [47-49]. In addition to saline and alkaline elements, this powder contains crystalline, dry lakebed sediments, toxic chemicals, and harmful heavy metal particles, which threaten plant survival and increase the desert area. The affected desert area has reached $67 \mathrm{~km}^{2}$ [42], and is threatening the livestock and human lives in the surrounding area.

\subsection{Evaluation of Effective Management Plan For Ebinur Lake}

Fluctuations in water levels alter lake morphometrics and transform the characteristics of the sedimentation zones. Water level fluctuations may also influence habitat diversity by altering substrate availability [50] and the coverage and diversity of shoreline vegetation [51,52]. The amplitude of the fluctuations, which is the difference between the maximum and minimum levels, depends on human water use and regional climate changes $[8,40]$. The Ebinur Lake is shallow with an average depth of only $1.3 \mathrm{~m}$ [53]. Thus, the lake area is very sensitive to the WLFs. As a result, the lake area always changes in size, likely due to the extreme weather effects (dry or wet seasons). This scenario is because the ecological effects of WLFs in lakes are the greatest in lake shoreline zones, where small draw-downs in lake water level can result in the conversion of large areas of standing water to air-exposed habitats and dry lake bed crust (Figure 7). Furthermore, because of high evapotranspiration and low rainfall, regions where evaporation occurs on the edges or shallow areas of the Ebinur Lake area are prone to salinization. Then, the top salt and saline soils on the dry lake bed crust in the Ebinur can be blown by wind erosion. The salt powder in the form of suspended particles in the air becomes a natural disaster accompanied with strong wind; it can affect plant, animal, and human life in the region and surrounding areas. Unfortunately, Ebinur Lake located in the wind airflow area of the Great Passage of the Alashankou, a famous desert wind storm with a maximum wind speed of up to $55 \mathrm{~m} / \mathrm{s}$. The Ebinur Lake region, for an average of 164 days annually, has strong winds at Beaufort 8 or higher according to the wind scale reported by $\mathrm{Wu}$ and $\mathrm{Lin}$ (2004) [38].

Salt and alkaline dust storms are generally caused by lack of water resources or extreme weather (dry season) effects around the lake area constantly shrinking and the dry lake bed crust blown by wind erosion. In contrast, when the lake water supplies heavy precipitation and abundant runoff (wet season), the lake area is sharply increased, and the lake water submerges the surrounding area, submerging shrubs, plants, and other agricultural crops; it can even be threatening to residential areas. In 2002, this lake area suffered from a flood disaster [42]. Therefore, variation of the Ebinur Lake area has a negative ecological impact on the environment and on the human life and property of this study region. We present results of that study here to demonstrate quantitatively that lake water levels are a controlling factor in determining composition and potential zonation in Ebinur Lake eco-environment changes. For this purpose, we combine remote sensing observations with hydrological modelling for surface water area monitoring of Ebinur Lake, and the results show the variation in the lake surface area and length of shore line during 1998. The lake surface area decreased from approximately $669.39 \mathrm{~km}^{2}$ (11 April 1998) to approximately $409.18 \mathrm{~km}^{2}$ (23 October 1998) and at the same time the length of the shore line decreased from $168.18 \mathrm{~km}$ to $96.16 \mathrm{~km}$. The seasonal changes from water levels can be as large as more than $1 \mathrm{~m}$; thus, lake shoreline displacements can be as large as hundreds of kilometers. The results of the depth-area-volume relationships are also positively 
correlated with each other as shown in Figure 8. If the water level reaches $192.15 \mathrm{~m}$ above sea level (m.a.s.l.), the lake surface area reaches $602 \mathrm{~km}^{2}$, and the volume reaches $13.5 \times 10^{8} \mathrm{~m}^{3}$. These results support the concept of the water balance model and support the hypothesis that water level fluctuations play a significant role in lake shoreline displacement variation and indirectly affect vegetation and biota dynamics of Ebinur Lake. Therefore, WLF is regarded as a crucial factor for Ebinur Lake ecosystem functioning and affects conservation values.

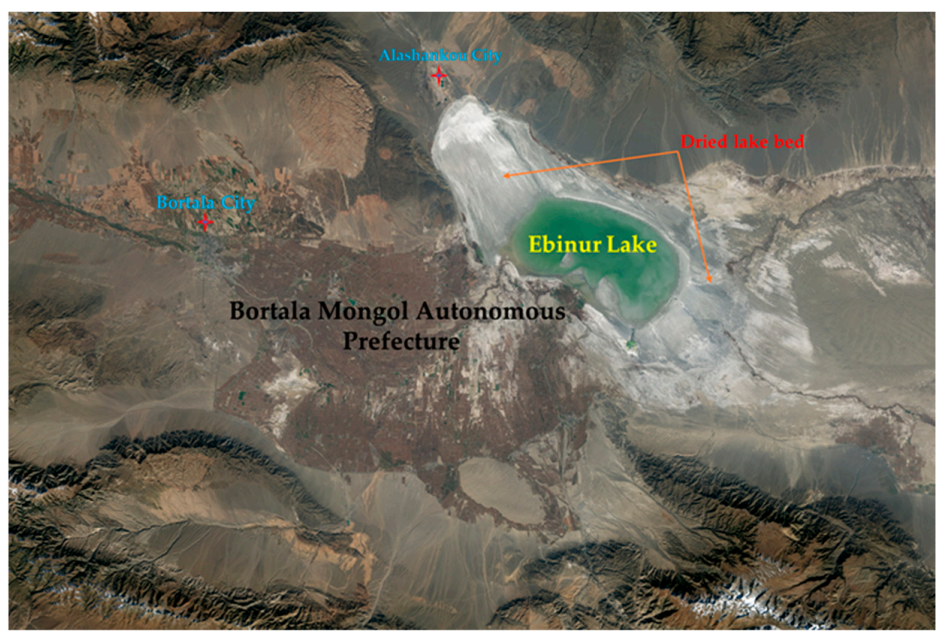

Figure 7. Water surface area of Ebinur Lake and dried lake bed.
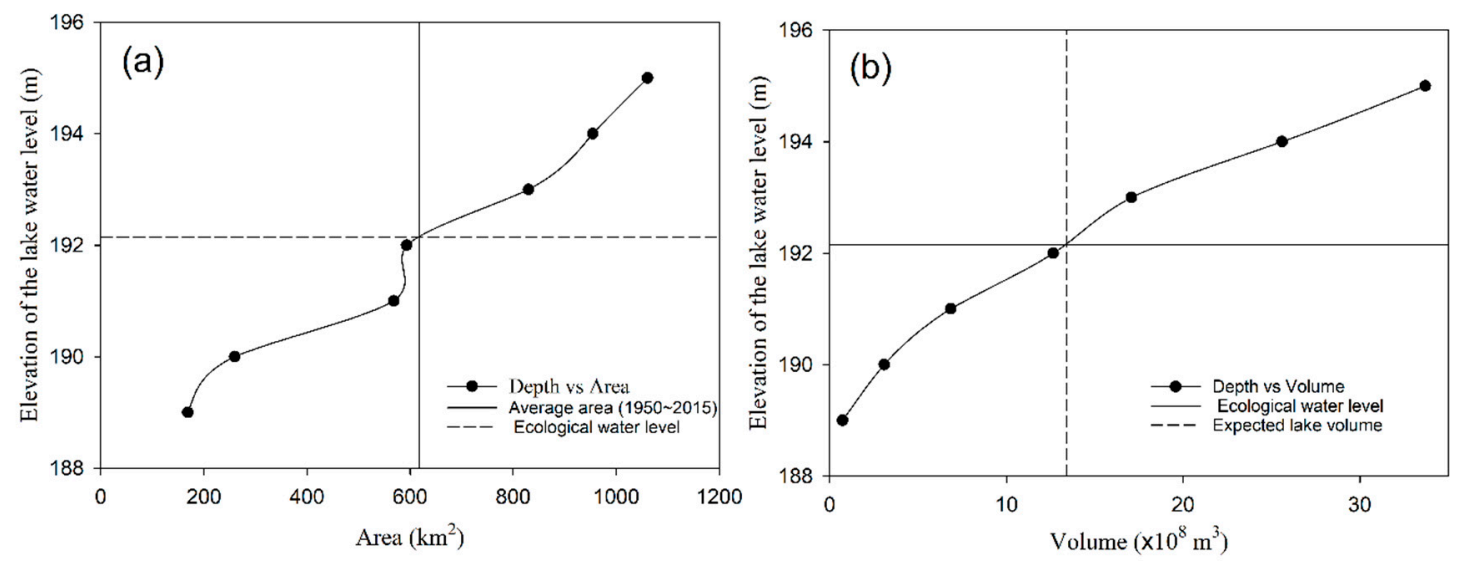

Figure 8. Depth-area-volume curves. Plot (a) is depth vs. area. Plot (b) is depth vs. volume.

\subsection{Implications}

Ebinur wetlands were the only ecosystems formed as a result of land and water interactions. The Ebinur Lake is one of the most complete natural lakes in this natural wetland, which has a unique wetland ecological environment and rich biodiversity resources. This lake plays an important role in many ecosystems by mitigating pollution, providing habitats for plants and wildlife, regulating climate, and preserving biodiversity in the Ebinur Lake wetland nature reserve. The ecological environmental changes of Ebinur Lake have been studied by many researchers over recent decades [54-56], however, the ecological and environmental response to climate change and intensified human activities have not been studied, especially the temporal scaling of the lake water level fluctuations effects. The magnitude and frequency of WLFs in Ebinur Lake are also evident in the wetlands, where slight changes in water levels can have important effects on their size and distribution. Our study showed that contrasting water-level regimes drive major differences in the ecology of lake littoral zones, influencing not only the littoral habitat structure but also ecological and environmental degradation in the lake area. Various studies have underlined the importance of water level fluctuations, which play a significant 
role in lake shoreline displacements, which again may cause changes in littoral vegetation structures, affecting their ecological functions. Water level fluctuations strongly influence wetland vegetation patterns, regardless of seasonal fluctuations [57], annual fluctuations [58,59], or extreme events [11]. Our findings are similar to those of earlier research - the alterations in the natural patterns of WLFs can compromise not only the ecological integrity of lakes [60-64], but also the provision of ecosystem goods and services, and the sustainable use and management of standing water bodies in the face of a multitude of adverse human impacts [65-67]. This scenario occurs because the ecological effects of WLFs in lakes are likely to be greatest in littoral zones [68,69], where even small draw-downs can result in the conversion of large areas of standing water to air-exposed habitats and vice versa [70]. Recently, studies showed that intermittently exposed lake bottoms of dry lakes in the Ebinur Lake wetlands are the primary source for salt dust storms in the surrounding area [70]. When the water level is too high, the lake area increased, and the lake water submerged the surrounding area, causing surrounding soil drainage difficulties, the formation of salinization, and submergence of shrub and other plants, which resulted in plants drowning because their roots have mitochondria (which supply the plant with energy to survive) that need air that they take from the air spaces in the soil. In addition, increases in lake area will increase the groundwater table, causing agricultural cultivated soil salinization; furthermore, these increases in area will threaten the safety of industrial enterprises and traffic routes in surrounding areas of the lake. Therefore, controlling variations in the water level is a vital physical factor to managing the Ebinur Lake ecosystems for conservation and restoration.

\section{Conclusions}

In this paper, we develop a lake water balance model using the System Dynamics (SD) method to expose the variation and relationship between the lake depth-area-volume, and highlight the importance of temporal scales when considering water level fluctuation impacts on a lake ecosystem. We documented and evaluated the variation in regional hydrological characteristics and potential risks of the ecological effects in the wetlands of the Ebinur Lake basin. Our results demonstrated that this lake has become very sensitive to interactions between the human and the natural environment. Under the influence of regional climate change and human activities, this area has been shrinking, its pollution has increased substantially, and the ecological environment has become worse. The results of the water balance model showed that the monthly water volume changes in Ebinur Lake and that the amounts of inflow were more than the outflow in 1998, and the residual value of out-inflow was $0.67 \times 10^{8} \mathrm{~m}^{3}$. The relationship of the water level-area-volume analysis showed that there is a positive correlation between each factor; if the lake level reached 192.5 m.a.s.l., the lake area is approximately $602 \mathrm{~km}^{2}$, and the volume is close to $13.5 \times 10^{8} \mathrm{~m}^{3}$. The changes in water levels can have important effects on lake size and lake shoreline displacements, and can indirectly impact a lake eco-environment. This study highlighted that the controlling of the lake water level fluctuations is the most important hydrological factor to guarantee the sustainable development of the Ebinur Lake ecosystem.

Author Contributions: The research article is the joint work with five authors. Conceptualization, B.M.; Data curation, B.M. and Z.S.; Formal analysis; B.M and Y.A.; Funding acquisition, B.M. and Z.S.; Investigation, B.M. and Z.S.; Mythology, B.M., Y.A. and T.A.; Project administration, Z.S. and S.Y.; Supervision, S.Y.; Validation, B.M., Y.A. and T.A.; Writing-original draft, B.M.; Writing-review \& editing, Y.A. and T.A. All authors have read and agreed to the published version of the manuscript.

Funding: The research was carried out with the financial support provided by the grants from the National Natural Science Foundation of China (grant No. 41762019; grant No. U1603241; grant No. 31700386), the Thousand Youth Talents Plan of China (Xinjiang Projects), and supported by a grant from Xinjiang University Fund for Distinguished Young Scholars (grant No. BS160232).

Acknowledgments: The authors would like to thanks who assisted long and strenuous hours to collect field data. We also thank the Key Laboratory of Oasis Ecology Xinjiang University for their support in providing data and discussion during the research. We are extremely thankful to an anonymous reviewer and editor for valuable comments that have greatly improved the clarity of this article.

Conflicts of Interest: The authors declare that there is no conflict of interests regarding the publication of this paper. 


\section{References}

1. Gownaris, N.J.; Rountos, K.J.; Kaufman, L.; Kolding, J.; Lwiza, K.M.M.; Pikitch, E.K. Water level fluctuations and the ecosystem functioning of lakes. J. Great Lakes Res. 2018, 44, 1154-1163. [CrossRef]

2. Kolding, J.; van Zwieten, P.A.M. Relative lake level fluctuations and their influence on productivity and resilience in tropical lakes and reservoirs. Fish. Res. 2012, 115-116, 99-109. [CrossRef]

3. Usmanova, R.M. Aral Sea and sustainable development. Water Sci. Technol. 2003, 47, 41-47. [CrossRef]

4. Stephens, D.W. Changes in lake levels, salinity and the biological community of Great Salt Lake (Utah, USA), 1847-1987. Hydrobiologia 1990, 197, 139-146. [CrossRef]

5. Bourne, J.K.; Joel, K.; Ludwig, G. Eccentric Salton Sea. Natl. Geogr. Mag. 2005, 207, 88-107.

6. Naselli-Flores, L.; Barone, R. Water-Level Fluctuations in Mediterranean Reservoirs: Setting a Dewatering Threshold as a Management Tool to Improve Water Quality. Hydrobiologia 2005, 548, 85-99. [CrossRef]

7. McGowan, S.; Leavitt, P.R.; Hall, R.I. A whole-lake experiment to determine the effects of winter droughts on shallow lakes. Ecosystems 2005, 8, 694-708. [CrossRef]

8. Liu, X.; Yang, Z.; Yuan, S.; Wang, H. A novel methodology for the assessment of water level requirements in shallow lakes. Ecol. Eng. 2017, 102, 31-38. [CrossRef]

9. Midwood, J.D.; Chow-Fraser, P. Changes in aquatic vegetation and fish communities following 5 years of sustained low water levels in coastal marshes of eastern Georgian Bay, Lake Huron. Glob. Chang. Biol. 2012, 18, 93-105. [CrossRef]

10. Paillisson, J.-M.; Marion, L. Water level fluctuations for managing excessive plant biomass in shallow lakes. Ecol. Eng. 2011, 37, 241-247. [CrossRef]

11. Wantzen, K.M.; Rothhaupt, K.-O.; Mörtl, M.; Cantonati, M.; G.-Tóth, L.; Fischer, P. Ecological effects of water-level fluctuations in lakes: An urgent issue. Hydrobiologia 2008, 613, 1-4. [CrossRef]

12. Zhang, G.; Xie, H.; Yao, T.; Kang, S. Water balance estimates of ten greatest lakes in China using ICESat and Landsat data. Chin. Sci. Bull. 2013, 58, 3815-3829. [CrossRef]

13. Manzur, M.E.; Grimoldi, A.A.; Insausti, P.; Striker, G.G. Escape from water or remain quiescent? Lotus tenuis changes its strategy depending on depth of submergence. Ann. Bot. 2009, 104, 1163-1169. [CrossRef] [PubMed]

14. Mahoney, J.M.; Rood, S.B. Streamflow requirements for cottonwood seedling recruitment-An integrative model. Wetlands 1998, 18, 634-645. [CrossRef]

15. Merritt, D.M.; Scott, M.L.; Leroy, P.N.; Auble, G.T.; Lytle, D.A. Theory, methods and tools for determining environmental flows for riparian vegetation: Riparian vegetation-flow response guilds. Freshw. Biol. 2010, 55, 206-225. [CrossRef]

16. Yu, L.; Yu, D. Differential responses of the floating-leaved aquatic plant Nymphoides peltata to gradual versus rapid increases in water levels. Aquat. Bot. 2011, 94, 71-76. [CrossRef]

17. Shiri, J.; Shamshirband, S.; Kisi, O.; Karimi, S.; Bateni, S.M.; Hosseini Nezhad, S.H.; Hashemi, A. Prediction of Water-Level in the Urmia Lake Using the Extreme Learning Machine Approach. Water Resour. Manag. 2016, 30, 5217-5229. [CrossRef]

18. Morrill, C.; Small, E.E.; Sloan, L.C. Modeling orbital forcing of lake level change: Lake Gosiute (Eocene), North America. Glob. Planet. Chang. 2001, 29, 57-76. [CrossRef]

19. Bracht-Flyr, B.; Istanbulluoglu, E.; Fritz, S. A hydro-climatological lake classification model and its evaluation using global data. J. Hydrol. 2013, 486, 376-383. [CrossRef]

20. Soja, G.; Züger, J.; Knoflacher, M.; Kinner, P.; Soja, A.-M. Climate impacts on water balance of a shallow steppe lake in Eastern Austria (Lake Neusiedl). J. Hydrol. 2013, 480, 115-124. [CrossRef]

21. Torabi Haghighi, A.; Kløve, B. A sensitivity analysis of lake water level response to changes in climate and river regimes. Limnologica 2015, 51, 118-130. [CrossRef]

22. Cao, T.; Yi, Y.; Liu, H.; Yang, Z. Integrated ecosystem services-based calculation of ecological water demand for a macrophyte-dominated shallow lake. Glob. Ecol. Conserv. 2020, 21, e00858. [CrossRef]

23. Forrester, J.W. Industrial Dynamics; MIT Press: Cambridge, MA, USA, 1961.

24. Ahmad, S.; Prashar, D. Evaluating municipal water conservation policies using a dynamic simulation model. Water Resour. Manag. 2010, 24, 3371-3395. [CrossRef]

25. Qaiser, K.; Ahmad, S.; Johnson, W.; Batista, J.R. Evaluating water conservation and reuse policies using a dynamic water balance model. Environ. Manag. 2013, 51, 449-458. [CrossRef] 
26. Rusuli, Y.; Li, L.; Ahmad, S.; Zhao, X. Dynamics model to simulate water and salt balance of Bosten Lake in Xinjiang, China. Environ. Earth Sci. 2015, 74, 2499-2510. [CrossRef]

27. Choubin, B.; Khalighi-Sigaroodi, S.; Malekian, A.; Ahmad, S.; Attarod, P. Drought forecasting in a semi-arid watershed using climate signals: A neuro-fuzzy modeling approach. J. Mt. Sci. 2014, 11, 1593-1605. [CrossRef]

28. Kalra, A.; Ahmad, S.; Nayak, A. Increasing streamflow forecast lead time for snowmelt-driven catchment based on large-scale climate patterns. Adv. Water Resour. 2013, 53, 150-162. [CrossRef]

29. Dawadi, S.; Ahmad, S. Evaluating the impact of demand-side management on water resources under changing climatic conditions and increasing population. J. Environ. Manag. 2013, 114, 261-275. [CrossRef]

30. Butler, C.; Adamowski, J. Empowering marginalized communities in water resources management: Addressing inequitable practices in Participatory Model Building. J. Environ. Manag. 2015, 153, 153-162. [CrossRef]

31. Yaeger, M.A.; Housh, M.; Cai, X.; Sivapalan, M. An integrated modeling framework for exploring flow regime and water quality changes with increasing biofuel crop production in the U.S. Corn Belt. Water Resour. Res. 2014, 50, 9385-9404. [CrossRef]

32. Valipour, M. Future of agricultural water management in Africa. Arch. Agron. Soil Sci. 2015, 61, 907-927. [CrossRef]

33. Abadi, L.S.K.; Shamsai, A.; Goharnejad, H. An analysis of the sustainability of basin water resources using Vensim model. KSCE J. Civ. Eng. 2015, 19, 1941-1949. [CrossRef]

34. Alifujiang, Y.; Abuduwaili, J.; Ma, L.; Samat, A.; Groll, M. System Dynamics Modeling of Water Level Variations of Lake Issyk-Kul, Kyrgyzstan. Water 2017, 9, 989. [CrossRef]

35. Wang, X.; Zhang, F.; Kung, H.; Ghulam, A.; Trumbo, A.L.; Yang, J.; Ren, Y.; Jing, Y. Evaluation and estimation of surface water quality in an arid region based on EEM-PARAFAC and 3D fluorescence spectral index: A case study of the Ebinur Lake Watershed, China. CATENA 2017, 155, 62-74. [CrossRef]

36. Abuduwaili, J.; Gabchenko, M.V.; Junrong, X. Eolian transport of salts-A case study in the area of Lake Ebinur (Xinjiang, Northwest China). J. Arid Environ. 2008, 72, 1843-1852. [CrossRef]

37. Li, Y.; Chu, X.; Jin, H. Study on changes of hydrological charactericteristies of Ebinur lake basin in Xinjiang. J. China Hydrol. 2006, 26, 68-71.

38. Wu, J.; Lin, L. Characteristics and reasons of fluctuation of lake surface of the Aibi Lake, Xinjiang autonomous region. Mar. Geol. Quat. Geol. 2004, 24, 57-60.

39. Ragni, M.; Steffenhagen, F.; Klein, A. Generalized dynamic stock and flow systems: An AI approach. Cogn. Syst. Res. 2011, 12, 309-320. [CrossRef]

40. Lei, Y.; Yao, T.; Yang, K.; Bird, B.W.; Tian, L.; Zhang, X.; Wang, W.; Xiang, Y.; Dai, Y.; Lazhu; et al. An integrated investigation of lake storage and water level changes in the Paiku Co basin, central Himalayas. J. Hydrol. 2018, 562, 599-608. [CrossRef]

41. Kummu, M.; Tes, S.; Yin, S.; Adamson, P.; Józsa, J.; Koponen, J.; Richey, J.; Sarkkula, J. Water balance analysis for the Tonle Sap Lake-floodplain system. Hydrol. Process. 2014, 28, 1722-1733. [CrossRef]

42. Jia, C.G.; Wang, X.F.; Yang, L.; Wang, H.W. A Preliminary Study on the Influence of Water-level Change of the Ebinur Lake on Eco-efficiency in the Lake Area. J. Xinjiang Norm. Univ. Nat. Sci. Ed. 2005, 24, 141-144.

43. Bai, X. Study on the wetland ecological vulnerability and its driving system in Ebinur lake in XinJiang. East China Norm. Univ. Shanghai China 2010, 38-46.

44. Zhu, X.; Huang, P. Ecological Environment Deterioration of Aibi Lakeside and Its Countermeasures. Environ. Prot. Xinjiang 2004, 26, 36-38.

45. Zhang, Z.; Abuduwaili, J.; Jiang, F. Sources, pollution statue and potential ecological risk of heavy metals in surface sediments of aibi lake, northwest china. Environ. Sci. 2015, 36, 490-496.

46. Evtimova, V.V.; Donohue, I. Water-level fluctuations regulate the structure and functioning of natural lakes. Freshw. Biol. 2016, 61, 251-264. [CrossRef]

47. Abuduwaili, J.; Xu, J.R.; Mu, G.J. Effect of soil dust from Ebinur Lake on soil salts and landscape of surrounding regions. J. Glaciol. Geocryol. 2007, 29, 928-939. [CrossRef]

48. Liu, D.; Abuduwaili, J.; Lei, J.; Wu, G.; Gui, D. Wind erosion of saline playa sediments and its ecological effects in Ebinur Lake, Xinjiang, China. Environ. Earth Sci. 2011, 63, 241-250. [CrossRef]

49. Abuduwaili, J.; Liu, D.; Wu, G. Saline dust storms and their ecological impacts in arid regions. J. Arid Land 2010, 2, 144-150. [CrossRef] 
50. Gafny, S.; Gasith, A. Spatially and temporally sporadic appearance of macrophytes in the littoral zone of Lake Kinneret, Israel: Taking advantage of a window of opportunity. Aquat. Bot. 1999, 62, 249-267. [CrossRef]

51. Hill, N.M.; Keddy, P.A.; Wisheu, I.C. A Hydrological Model for Predicting the Effects of Dams on the Shoreline Vegetation of Lakes and Reservoirs. Environ. Manag. 1998, 22, 723-736. [CrossRef]

52. Janssen, A.B.G.; Teurlincx, S.; An, S.; Janse, J.H.; Paerl, H.W.; Mooij, W.M. Alternative stable states in large shallow lakes? J. Great Lakes Res. 2014, 40, 813-826. [CrossRef]

53. Zhang, F.; Kung, H.; Johnson, V. Assessment of Land-Cover/Land-Use Change and Landscape Patterns in the Two National Nature Reserves of Ebinur Lake Watershed, Xinjiang, China. Sustainability 2017, 9, 724. [CrossRef]

54. Yusupjan, A.; Alimujiang, K.; Abdusalam, R. Information extraction and dynamic area change in Ebinur Lake Wetland based on RS and GIS. Water Resour. Prot. 2014, 30, 57-61.

55. Zhao, X.; Chu, X.; Ma, X.; Mo, F. Ebinur Lake Wetland vegetation coverage in response to a micro-climate change. Pratacult. Sci. 2017, 36, 1168-1177.

56. Hao, S.; Li, F.; Li, Y.; Gu, C.; Zhang, Q.; Qiao, Y.; Jiao, L.; Zhu, N. Stable isotope evidence for identifying the recharge mechanisms of precipitation, surface water, and groundwater in the Ebinur Lake basin. Sci. Total Environ. 2019, 657, 1041-1050. [CrossRef] [PubMed]

57. Strang, I.; Dienst, M. Effects of water level at Lake Constance on the Deschampsietum rhenanae from 1989 to 2003. Limnologica 2004, 34, 22-28. [CrossRef]

58. Wilcox, D.A.; Nichols, S.J. The effects of water-level fluctuations on vegetation in a Lake Huron wetland. Wetlands 2008, 28, 487-501. [CrossRef]

59. Wilcox, D.A.; Xie, Y. Predicting wetland plant community responses to proposed water-level-regulation plans for Lake Ontario: Gis-based modeling. J. Great Lakes Res. 2007, 33, 751-773. [CrossRef]

60. Zohary, T.; Ostrovsky, I. Ecological impacts of excessive water level fluctuations in stratified freshwater lakes. Inland Waters 2011, 1, 47-59. [CrossRef]

61. Deegan, B.M.; White, S.D.; Ganf, G.G. Nutrients and water level fluctuations: A study of three aquatic plants. River Res. Appl. 2012, 28, 359-368. [CrossRef]

62. Yin, X.A.; Yang, Z.F. A method to assess the alteration of water-level-fluctuation patterns in lakes. Procedia Environ. Sci. 2012, 13, 2427-2436. [CrossRef]

63. Ostendorp, W.; Dienst, M.; Schmieder, K. Disturbance and rehabilitation of lakeside Phragmites reeds following an extreme flood in Lake Constance (Germany). Hydrobiologia 2003, 506-509, 687-695. [CrossRef]

64. Wang, W.; Yin, C. The boundary filtration effect of reed-dominated ecotones under water level fluctuations. Wetl. Ecol. Manag. 2008, 16, 65-76. [CrossRef]

65. Schmieder, K.; Dienst, M.; Ostendorp, W. Effects of the extreme flood in 1999 on the spatial dynamics and stand structure of the reed belts in Lake Constance. Limnologica 2002, 32, 131-146. [CrossRef]

66. Palmer, M.A. Beyond infrastructure. Nature 2010, 467, 534-535. [CrossRef] [PubMed]

67. Jiang, H.; Wen, Y.; Zou, L.; Wang, Z.; He, C.; Zou, C. The effects of a wetland restoration project on the Siberian crane (Grus leucogeranus) population and stopover habitat in Momoge National Nature Reserve, China. Ecol. Eng. 2016, 96, 170-177. [CrossRef]

68. Leira, M.; Cantonati, M. Effects of water-level fluctuations on lakes: An annotated bibliography. Hydrobiologia 2008, 613, 171-184. [CrossRef]

69. Zhang, X.; Liu, X.; Wang, H. Developing water level regulation strategies for macrophytes restoration of a large river-disconnected lake, China. Ecol. Eng. 2014, 68, 25-31. [CrossRef]

70. Ge, Y.; Abuduwaili, J.; Ma, L.; Wu, N.; Liu, D. Potential transport pathways of dust emanating from the playa of Ebinur Lake, Xinjiang, in arid northwest China. Atmos. Res. 2016, 178-179, 196-206. [CrossRef]

(C) 2020 by the authors. Licensee MDPI, Basel, Switzerland. This article is an open access article distributed under the terms and conditions of the Creative Commons Attribution (CC BY) license (http://creativecommons.org/licenses/by/4.0/). 